\title{
Correction to: John Schwenkler, Anscombe's Intention: A Guide. New York: Oxford University Press, 2019. ISBN978-0-19-005203-4, \$24.95, Pbk
}

\section{David K. Chan ${ }^{1}$}

Published online: 9 March 2021

(C) Springer Nature B.V. 2021

\section{Correction to: The Journal of Value Inquiry https://doi.org/10.1007/s10790-020-09787-6}

In the original publication of this article, the title of the article has been publihsed incorrectly. Now the same has been corrected and publihsed in this Correction.

Publisher's Note Springer Nature remains neutral with regard to jurisdictional claims in published maps and institutional affiliations.

The original article can be found online at https://doi.org/10.1007/s10790-020-09787-6.

David K. Chan

dkchan@uab.edu

1 Department of Philosophy, The University of Alabama at Birmingham, 1720 2nd Ave South, Birmingham, AL 35294-1241, USA 